\title{
Toponymy and Branding of Modern Residential Sites in Semarang
}

\author{
Nurhayati Nurhayati ${ }^{1, *}$, \\ ${ }^{1}$ Master Program of Linguistics, Faculty of Humanities, Diponegoro University, Semarang - Indonesia
}

\begin{abstract}
This study concerns with the phenomenon of naming residential areas using both local and foreign language and choosing lexicons relating to nature. Using critical toponymy and critical discourse analysis, 53 names were analyzed. The results show that blending both local language (the Indonesian) and English is the most popular. It is a branding strategy to create global society in local context. The use of certain lexicons referring to nature reveals that the developers concern with the movement of creating low-carbon society. They function as marketing strategy to control society in identify themselves as members of global society.
\end{abstract}

Keywords: critical toponymy; global society; living with nature.

\section{Introduction}

Toponymy as a scientific study of place names has interested researchers until now. Many topics pertaining to place names have been presented in toponymy conferences and published in various journals. The approach of toponymy have developed from descriptive toponymy to critical toponymy.[1]. Descriptive toponymy pays attention to gather place names and to describe the history behind them and linguistic structure composing them. Some studies relating to the discriptive toponymy were conducted by Kelly [2,3], Lance [4] McArthur [5], McCafferty [6], Lauder and Lauder [7], and Geospatial Information Agency of Indonesia [8].

On the other hand, critical toponymic studies mostly focus on uncovering the influence of socio cultural aspects such as intention, ideology, motive, and socio, economic and political agenda on the practice of naming places. Studies conducted by researchers such as Madden [9], Jordan [10, 11], Redwood and Alderman [12], and Ndlovu [13] reveal the critical purposes of toponymy. The critical studies show that practice of naming places has close relationship with the other social practices such as building nation, legitimating power, and establishing ideologies. Critical toponymy has been one of the important social studies in the modern era.

In Indonesia, most of the toponymic studies were conducted descriptively aiming at describing the histirocal and cultural heritage [14], or at standardization [7],8]. Eventhough some conferences focussed on topics of toponymy, as far as I know, there is no literature discussing the social motives of practicing naming modern residential places. This is an intersting phenomenon because a prelimiary observation showed that many real estate developers in big cities of Indonesia named their products (apartments, clusters, townhouses, and resorts) using English instead of the Indonesian or local language.
As many other big cities in the world, Semarang is developing to be an urban city. Many people coming from other cities or even other coutries. They need a temporary or permanent place to stay. The raising demand gives property developers opportunities to build new residence. Various strategies are applied to sell houses or apartments. One of them is through giving certain names for the new places representing the identity of the residents. Based on the idea, I assume that naming new places is not arbitrer but motivated. Naming is a discourse practice together with other social practices such as marketing, constructing identities, and branding [15]. The study aims to explain the socio, economic, and cultural motives behind the practice of naming modern residential places in Semarang. To achieve the purpose, I answer three research questions: (i) what linguistic propertis used to practice naming; (ii) what contexts motivate the developers as the text producers to do such naming; and (iii) how do the discourse practice of naming influences the social structure in the city. The result of the study shows that the practice of naming residences is a discourse practice aiming to change social identity of the residences from local or national residences to global ones. That is a strategy to give branding to the developers, so they can increase their market.

\section{Research Methods}

Toponymy as a scientific study of place names has interested The research was based on the observation of 21 modern residential areas in Semarang city. Data are place names created by the developers of the areas and were taken from the websites of the developers. The unit of analysis is words or phrases as manifests of place names in the residential areas. The data were analysed using a critical discourse analysis (CDA) approach as proposed by Fairclough $[15,16]$. Three stages in CDA, description, interpretation, and explanation,

* Corresponding author: noerhytwid@yahoo.com 
were applied as a method of analysing data qualitatively. In description and interpretation stages, I also used an approach that is called intensive toponymy [17] focusing on exploring information about the agent giving names, the time of naming, the meaning of names. Description of linguistic data was done using morphology and semantic approaches to get information about the features and denotative meaning of the place names. The language origin of the place names was also identified. Interpretation of the data was conducted through relating the linguistic properties and both situational and textual contexts [16]. Social and economic theories relating to the global society and advertising were used to discover the discourse meaning and the non-discoursal elements influencing the practice of naming places. The explanation stage was conducted through relating the discourse practice of naming and the social structure [16]. to the developers, so they can increase their market.

\section{The Origins of Modern Residential Place Names in Semarang}

Data analysis shows that place names refering to the residential housing were created using both English and the Indonesian language. They are used independently as monolingual names or they are mixed in the form of phrase mixing as illustrated in Chart 1.

As depicted in Chart 1, there are three patterns in giving place names to residential sites in Semarang : pure Indonesian language, pure English, and mix of English and Indonesian languages. The tendency of creating the place names into the three patterns has a correlation with other non-linguistic elements., such as text producers, text receivers, properties which are offered, goal of naming, and other socio-cultural contexts.

Indonesian place names are not popular among the new residential properties in Semarang. There are only five place names using pure Indonesian : Griya Indah Kradenan, Bukit Mutiara Jaya, Jamrud, Ruko Panorama, and Graha Taman Pelangi. Choosing the Indonesian language to name residential area may imply that the developers tend to use local perspective. The data show that the developers use the words griya and graha, the ancient version of rumah. The formers sound elegant. The two words were used to refer the houses of the Javanese Royale. Therefore, choosing the words griya and graha, the developers may aim to interest consumers' attention. Using the two words results stylistic effects that can not be produced when the text producers use the word rumah. Tendency to use ancient Javanese words may also bring back past memories.

Pure English words or phrases are used to name sixteen places. They are Emerald Garden, Emerald, Riverside, Golden Wood, Yellow Leaf, Green Stone, Grandwalk, Green Royale, Ivy Park, The Forest Hill, Victoria Valley, D'Boulevard, and De Java Town House. The English names are generally applied to zonas or clusters. Similar to the reason of choosing Indonesian language, the developers may have certain intentions or motives, instead of being arbitrer. The common motives in using English for the place names may be to construct global identity of the resident and the potential buyers. Using the global perspective, the developers aim to provide world nuanced residential sites, and as a result, the occupants may percieve themselves as part of global society. From the data, it can be seen that the text producer also insert the French's particle $d$ or $d e$ in two names, those are D'Boulevard, and De Java Town House. Although, it is inappropriate linguistically, the use of $d$ or $d e$ may be intended to give the styllistic effect as a marketing strategy.

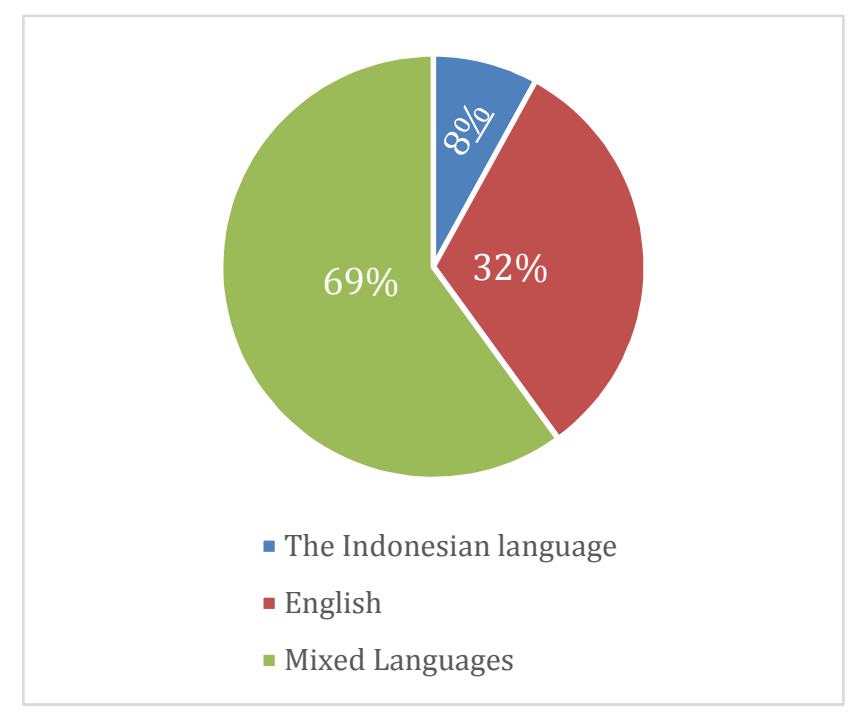

Chart 1. The Language Origin of the Place Names

Compared to the two previous strategies in naming the residential properties, the third one, that is mixing English and the Indonesian language is the most popular. There are 32 names found in the data The Green Royal Pudak Payung, Perumahan Kampoeng Symphony, Citra Sun Garden Semarang, Nirwana Hill, Perumahan Bukit Emerald JayaTembalang, Siranda Hill, Pandanaran Height, Ruko Pandanaran Terrace, Citra Grand, Pandanaran village, Bukit Violan Jaya, Siranda Hills, Ruko Bukit Kencana Jaya Avenue, Graha Candi Golf, BSB City, Citraland BSB City, Villa Mutiara Tembalang, Townhouse of Ketileng, Jungli Townhouse, Pudak Payung Townhouse, Pandanaran Height Cartenz, Pandanaran Height Vinson, Pandanaran Height Sierra, Panadanaran Height Austen, Pandanaran Village Emerald, Pandanaran Village Sapphire, Naraya Residence, Puri Arga Golf, Graha Taman Bunga Botanica, Graha Taman Bunga Floresia, and Graha Taman Bunga Arcadia.

The pattern of constructing the place names using two languages results some interpretation. First, it reveals the condition of the people of Semarang, or of Indonesia in general, as bi- or multilingual society. The Indonesian language is still their first or second language and English is a foreign language. Second, using the Indonesian lexicons is an index of location or the brand names of their developers. The word citra in Citra Sun Garden is an index of Ciputra Development company. The phrases Pudak Payung in The Green Royal Pudak Payung is an index of location of the residential houses. Third, the discourse praxis of mixing English and the Indonesian language in naming may be interpreted as glocal strategy in marketing.

Connected to the wave of global social change, an increasing tendency to use English names to residential sites, whether or 
not they are mixed with the local names, is an impact of fourth wave of industrial revolution. English becomes a device to unify local or regional society into the world. English becomes one of the world languages. Therefore, the English content in local products, including residential products, implies the motives of the developers to globalize the residential sites as well as their inhabitants.

\section{Social Representation in Naming Discourse}

The act of naming as one kind of discourse practices is a way to represent certain aspects of the world [15]. In the data, linguistic properties realizing the representation are nouns or noun groups. The linguistic properties function to represent thing and its modifier [18]. The things represented and the way the text producers represented things can be seen in Table 1.

Table 1. Linguistic Elements of Representation

\begin{tabular}{|c|c|c|}
\hline & THINGS & MODIFIER \\
\hline Settlement & $\begin{array}{l}\text { City, village, } \\
\text { kampoeng }\end{array}$ & \\
\hline Street & $\begin{array}{l}\text { Avenue, boulevard, } \\
\text { walk, side }\end{array}$ & \\
\hline Ground & Garden, park, & \\
\hline Landform & $\begin{array}{l}\text { Montana, sierra,hill, } \\
\text { height, valley }\end{array}$ & $\begin{array}{l}\text { River, rivera, } \\
\text { Montana, }\end{array}$ \\
\hline Colour & & Green, yellow, \\
\hline $\begin{array}{l}\text { Forms of } \\
\text { residences }\end{array}$ & $\begin{array}{l}\text { Town-house, villa, } \\
\text { residence, terrace, } \\
\text { puri, perumahan } \\
\text { Griya, ruko, bukit, } \\
\text { graha }\end{array}$ & \\
\hline $\begin{array}{l}\text { Parts of } \\
\text { plant }\end{array}$ & Wood, leaf & $\begin{array}{l}\text { florensia, } \\
\text { botanica, } \\
\text { arcadia, ivy }\end{array}$ \\
\hline $\begin{array}{l}\text { Stone \& } \\
\text { Precious } \\
\text { material }\end{array}$ & $\begin{array}{l}\text { stone, emerald, } \\
\text { jamrud }\end{array}$ & $\begin{array}{l}\text { Amethyst, } \\
\text { golden, } \\
\text { mutiara }\end{array}$ \\
\hline Location & & $\begin{array}{l}\text { Semarang, } \\
\text { Pudak Payung, } \\
\text { Kradenan, } \\
\text { Tembalang, } \\
\text { Jungli, } \\
\text { Ketileng, } \\
\text { candi, Nirwana }\end{array}$ \\
\hline Quality & Royale, & $\begin{array}{l}\text { Royal, grand, } \\
\text { indah, }\end{array}$ \\
\hline Music & & Symphony \\
\hline Proper name & $\begin{array}{l}\text { Violan, cartenz, } \\
\text { vinson, austen, } \\
\text { naraya, }\end{array}$ & $\begin{array}{l}\text { Jaya, citra, } \\
\text { Bukit Kencana } \\
\text { Jaya, Siranda }\end{array}$ \\
\hline scenery & & $\begin{array}{l}\text { Panorama, } \\
\text { Pelangi, }\end{array}$ \\
\hline activity & & Golf \\
\hline
\end{tabular}

As demonstrated in Table 1, not all names represent the direct relation between language use and thing represented. The direct reference relation is only found in the words or group of words referring to forms of residences such as town-house, villa, residence, terrace, perumahan (housing), griya (house), ruko (shophouse), graha (house), and puri (castle), and to settlement such as city, village, and kampoeng (village). Other place names refer to entities such as street, ground, landform, part of plant, and precious material. The words that directly relate to places such as Semarang, Kradenan, Pudak Payung, and Jungli, function as modifiers, instead of the main entities.

It means that in giving name to a certain area, the text producer did not solely conduct performative act, but also conducted other discourse practice. The place names such as The Forest Hill, Victoria Valley, and Nirwana Hill, represent the residential sites as highlands. Other representations are picturing areas as garden, park, leaf, wood, florensia, botanica, arcadia, and ivy, either as things or as modifiers. All the lexicons that are used to realize things or entities refer the concept of nature. The concept of nature is also picturized using certain modifiers referring to scenery, such as panorama and pelangi (rainbow).

The such discourse practices are influenced by the shared knowledge among people that living back to nature is assosiated with the positive values of life such as healthy, fresh air, far from pollution, and tranquility. The discourse practice may also represent the life style tendency in global era, that is living in harmony with nature. There is an ideological perspective shown through the such naming, that the occupants are part of a low-carbon society. Theys ave nature, instead of exploit it.

Using the words refering to precious materials such as stone, emerald, jamrud, amethyst, golden, or mutiara (pearl), either as thing or modifier, to represent the residential sites results interpretation that the area they advertise is precious. It may symbolize the high social class of the occupants. The similar motive can be found in naming the area using the words royale, royal, and grand.

The above analysis informs us that in discourse practice of naming the residential sites, the text producers represented not only places and forms of residences, but also concept of living with nature and certain social class of the occupants. The such discourse practice is influenced by both situational and intertextual context.

Situationally, the discourse practice is articulated by the discourse producer in economic institution, especially in property domain. One of the main purposes of the developers as part of the economic institution is selling the product effectively. Viewed from the perspective, the discourse practice of naming places is one strategy in selling. Therefore, it can be said that the practice of naming is one form of advertising. The question that should be answer, then, is why in advertising the product the advertiser also represented the life style of living with nature and constructed the social class of the consumers. It can be explained through relating the marketing institution to the current ideological movements, those are the global society and the low-carbon society. Using the such ideological values, the property developers may articulate their power to control the way of thinking and the behaviour of society. This is the strategy of glocal marketing $[19,20]$. 


\section{Dialectic Relation between Naming Discourse and Branding}

As stated by Fairclough [16], discourse is shaped by the societal, institutional, and situational contexts stored as member resource (MR) of the society and in turn has a social effect on MR. On the first dimention, the discourse of using foreign languages in naming residential places are shaped by societal condition, that is the wave of 4.0 industrial era. This condition forces the development countries move to be part of global communities. Therefore, mastering 'world language', one of them is English, is a must. The discourse is also shaped by the institutional context, those are the marketing institution. The free trade era forces any institution to win free competition. Therefore, one strategy that can be done is through branding [21]. Promoting area as part of gobal sites and raising issues of low-carbon society shaped the discourse practice of naming places through blending English and the Indonesian language and using the words referring to nature. The developers create identity as 'global community that cares the

The such discourse, in turn, results the social effect on the MR of the society. Together with other similar discourse practices in using glocal languages, the discourse of naming places strengthen the MR of the society that creating the blend words of English and local language is a tool for creating brand of a product. There are many names in food, restaurants, public areas, and other products using blend languages.

Representing near nature life style through naming residential areas is also a branding strategy that may influence the behaviour of society. It is a kind of social campaign to build a low-carbon society in millenial age.

\section{Conclusion}

The research contributes to the understanding that viewed from critical toponymy, place names are texts manifesting both discourse and non-discourse practice. Analysing the texts using critical toponymy and critical discourse analysis comes to the conclusion that the developers of the modern residential sites in Semarang mostly use the ideological values of living with nature, preserving local values, and being global society as branding identity. The purpose of the branding construction is to influence the way of life and behaviour of the consumers. When the consumers behave as a part of the global society, they will choose the areas to live.

\section{References}

1. M.W. Wanjiru, K. Matsubara, J. Cult. Geo. 34, (2017)

2. M. H. Kelly. Names 47(1). (1999)

3. M. H. Kelly. Names 48(1). (2000)

4. D.M. Lance. Names 47(3). (1999)

5. L. Mc.Arthur. Names 48(3). (2000)

6. A.F. Lauder, M.R.M.T. Lauder. Wacana 16 (2) (2015)

7. M. McCafferty. Names 51 (2). (2003)

8. Geospatial Information Agency of Indonesia. E/CONF.105/86/CRP.86. (2017)

9. D.J. Madden. L.S.E. ISSN 0042-0980. (2017)

10. P. Jordan. Nomina Africana. J.N.S. of Southern Africa. 30(1). (2016)

11. P. Jordan. Onomàstica, A. S. O. 2. (2016)

12. R.R. Redwood, D. Alderman. ACME: Int. E-Journal for C.G. 10. (2011)

13. S.Ndlovu. Lit.J.L.C.L. 39.(2018)

14. F. P. Cacciafoco, N. B. Adzman, N. S. Bte Sharin. RGHT, Issue XII, Vol. 23-24. (2017)

15. N. Fairclough. Analysing Discourse : Textual Analysis for Social Research. (Routledge, London, 2003).

16. N. Fairclough. Language and Power. (Longman, London , 2001)

17. J. Tent. Names, 63 No. 2, p. 65-74 (2015)

18. M. A. K. Halliday., C. M. I. Matthiessen.( An Introduction to Functional Grammar. Routledge, London, 2004).

19. N. Papatya. A. I. J. of Contemp. Research Vol. 3 (10), (2013)

20. D. Luigi, V. Simona. S.B.E. Vol. 5(3). (2010)

21. M. Cristina Paganoni. J.M. vol.7. (2012) 